\title{
E-baby skin integrity: evidence-based technology innovation for teaching in neonatal nursing
}

\author{
E-baby integridade da pele: inovação tecnológica no ensino de enfermagem neonatal baseado em \\ evidências
}

\section{E-baby integridad de la piel: innovación tecnológica en la enseñanza de enfermería neonatal basado en evidencias}

\author{
Natália Del Angelo Aredes ${ }^{1}$ \\ Danielle Monteiro Vilela Dias ${ }^{2}$ (1) \\ Luciana Mara Monti Fonseca ${ }^{3}$ (B) \\ Suzanne Hetzel Campbell ${ }^{4}$ (i) \\ José Carlos Amado Martins ${ }^{5}$ (1) \\ Manuel Alves Rodrigues 5
}

1. Universidade Federal de Goiás.

Goiânia, GO, Brasil.

2. Centro Universitário Claretiano.

Batatais, SP, Brasil.

3. Universidade de São Paulo.

Ribeirão Preto, SP, Brasil.

4. University of British Columbia.

Vancouver, BC, Canadá.

5. Escola Superior de Enfermagem de

Coimbra. Coimbra, Portugal.

Corresponding author:

Natália Del Angelo Aredes.

E-mail: nataliadel.aredes@gmail.com

Submitted on $01 / 03 / 2018$.

Accepted on 05/24/2018.

DOI: 10.1590/2177-9465-EAN-2017-0424

\begin{abstract}
Objective: To develop and validate the serious game e-Baby: skin integrity along with a panel of experts. Method: Methodological research approaching the following development steps: scope definition, game format and functions, script and communication with software developers, creation of prototype with evaluation and production; and validation by four experts using the tool Heuristic Evaluation for Digital Educational Game. Results: The serious game was built in a 3D technology with multimedia including animation and scientific-based content. The educational technology was validated by the experts in all heuristics, and among the all 36 analyzed items. $18(50 \%)$ presented no errors, and regarding the remaining items with any error, none had more than $25 \%$ errors within levels 3 and 4, according to Nielsen's classification. Conclusion and implications for the practice: The validated serious game is a virtual simulation educational technology with potential to contribute with learning in nursing and with evidence-based clinical practice.
\end{abstract}

Keywords: Educational Technology; Child Health; Preterm; Preterm Infant; Evidence-Based Clinical Practice.

\section{REsUMO}

Objetivo: Desenvolver e validar o serious game e-Baby: integridade da pele junto a um painel de experts. Método: Pesquisa metodológica contemplando as etapas de desenvolvimento: definição de escopo, formato do jogo e suas funcionalidades, descrição do roteiro e comunicação com desenvolvedores, prototipagem com avaliação e produção; e validação junto a quatro experts utilizando o instrumento Heuristic Evaluation for Digital Educational Games. Resultados: O Serious game foi construído em 3D, com multimídia, incluindo animações e conteúdo embasado cientificamente. Validado pelos experts em todas as heurísticas, dentre os 36 itens analisados, 18 (50\%) foram considerados isentos de problemas, sendo que em nenhum dos itens houve mais que $25 \%$ de problemas classificados nos níveis 3 e 4 , segundo a classificação de Nielsen. Conclusão e implicações para a prática: O serious game é uma tecnologia educacional do tipo simulação virtual, validado, e com potencial para contribuir com a aprendizagem e a prática baseada em evidências.

Palavras-chave: Tecnologia Educacional; Saúde da Criança; Recém-Nascido Prematuro; Prática Clínica Baseada em Evidências.

\section{Resumen}

Objetivo: Desarrollar y validar el juego e-Baby: integridad de la piel junto a un panel de peritos. Método: La investigación metodológica contemplando las etapas de desarrollo: definición de alcance, formato del juego y sus funcionalidades, descripción del guion y comunicación con desarrolladores, prototipaje con evaluación y producción; y validación junto a cuatro peritos utilizando el instrumento Heuristic Evaluation for Digital Educational Games. Resultados: El serious game fue construido en 3D con multimedia incluyendo animaciones y contenido basado científicamente. Validado en todas las heurísticas, dentro todos los 36 ítems analizados, 18 (50\%) fueran considerados sin problemas, siendo que en ninguno de los ítems ocurrió más que $25 \%$ de problemas clasificados en los niveles 3 y 4 , segundo la clasificación de Nielsen. Conclusión e implicaciones para la práctica: El juego validado es una tecnología educativa del tipo simulación virtual con potencial para contribuir con e aprendizaje em enfermería y la práctica basada en evidencias.

Palabras clave: Tecnología Educacional; Salud del Niño; Recién Nascido Prematuro; Práctica Clínica Basada en la Evidencia. 


\section{INTRODUCTION}

With the technological advances and its increasing incorporation in the daily life of people in Brazil and in the world, impact has also been observed in education, especially since the advent of the personal computer. Following learning theorists who favor the active role of the student and the preparation of interesting and motivating situations in the process of learning and teaching by the professor, technological innovations have been highlighted as resource and support to teaching practice and access to information. ${ }^{1}$

Although this phenomenon occurs at all levels of education, this work focuses on the nursing course, and highlights its relevance and repercussion in the Brazilian Unified Health System (SUS - Sistema Único de Saúde), either by the number of professionals working in the area, or by the volume of care and interactions with the community carried out by them daily. Thus, it is strategic for the success of the health system to improve the nurses' training processes, actions guided by the Diretrizes Curriculares Nacionais (National Curricular Guidelines). ${ }^{2}$

Starting from the setting of nursing education built for SUS, it is necessary to look closely at the demands of nurses' clinical practice, so that the gaps can be addressed and solved in partnership with the academy.

In the area of child health, the theme of prematurity is highlighted, representing the leading cause of neonatal death worldwide (15.4\% - 0.965 million). In addition, in view of the fraction represented in the picture of deaths up to five years of age ( $44 \%$ occur in the neonatal period), prematurity becomes the main cause of global infant mortality, surpassing pneumonia. ${ }^{3}$ Brazil still holds the $10^{\text {th }}$ position in the ranking of countries, regarding the number of preterm births, corroborating the relevance of the topic. ${ }^{4}$

Therefore, it is recognized the need to invest in the qualification of health professionals for the care provided to preterm infants, initiating training efforts from undergraduate course by articulating theory and practice, strengthening the evidencebased clinical practice, and offering potentially significant and motivating learning experiences.

Nursing education based on constructivism, problematization, the articulation between research, teaching and care, student autonomy and the relaxation of strategies and learning methods are currently recommended..$^{2,5}$

In this way, pedagogical planning requires the professor to increasingly articulate the demands of the context of the health system and communities, from theory to practice in close collaboration and mutual feedback, and use of creativity to encourage students belonging to $\mathrm{Y}$ generation that potentially prefers to learn through technology. ${ }^{6}$

In this context, educational technologies are highlighted by offering students fast access to the growing range of information, possibilities of human-computer interaction in multimedia, making communication easier between peers and between professors and students, by granting autonomy and flexibility in the search and synthesis of information, for allowing fun and enhancing the understanding of certain contents. ${ }^{7}$

To date, resources for nursing teaching-learning subsidies, mediated by computer technology, have been created mainly in countries such as the United Kingdom, Canada and the United States, but more timidly in Brazil. Despite this, initiatives have been presented in the country, developing digital technologies to strengthen the teaching of both students and nursing professionals, including health education in the community through these technologies, in the topic of child and adolescent health. ${ }^{8,9}$

It should be noted that all the educational technologies developed above can be accessed free of charge through the link: http://gruposdepesquisa.eerp.usp.br/gpecca2/?page_id=23.

The topics listed to guide the development of technologies are based on the demands of society influenced by the epidemiology and scope of the care provided by the nurse in the health system.

The choice of theme was the integrity of the premature infant's skin, considering the importance of qualifying the care of the nurse and his/her team in the prevention of infections in this population, another significant cause of neonatal mortality considering the incomplete development of the skin that is the first the body's mechanical and immune defense line. ${ }^{10}$

Believing in the positive impact of computer technologies for nursing student learning, the objective of this work was to develop and validate the e-Baby serious game: skin integrity.

\section{LITERATURE REVIEW}

Serious games are compulsory educational games whose entertainment aspect is optional, but prevalent in their creations due to the graphic or fun aspects inherent to them. They have the capacity to reproduce board games, cards or other, in addition to being able to mimic real situations, some of them assuming a virtual simulation character, allowing training advantages such as reflection on the practice, possibility of reuse and error in a safe environment, and contact with educational content through lively and motivating interface. ${ }^{11}$

Currently, virtual simulation games represent a majority of the main genres of the educational category. ${ }^{12}$ Scholars have discussed the importance of innovating strategies and resources for learning with playability, assigning advantages such as flexibility of time and space for access, possibility of repetition, following user's learning pace and students' satisfaction in learning from games and other technologies considered to be motivating. ${ }^{9}$

A challenge still present in universities, when it comes to the use of technology in teaching, is the need to enable their members (students, professors and other professionals involved) 
to implement, since many are not aware how to handle them or even how to use them in learning settings. Measures of access to technology, training and technical support become crucial to overcome them.

As a result of access to devices such as microcomputers and mobile phones, as well as the Internet, young people have more encouraging numbers every year: mobile phones between 20 and 24 year olds reach $89.6 \%$ (almost as twice as the number of microcomputers, indicating mobile technology trend), and Internet access reaches values above $80 \%$ in the age groups between 15 and 24 years. ${ }^{13}$

Like technological devices, serious games have become popular among students due to motivation, and to facilitate the understanding of some contents due to the animations and immediate feedback, for eliciting reflections relevant to the practice, and for being a fun and unconventional way of learning. ${ }^{14}$

This way of learning is mediated by user interaction with a setting that simulates reality, but because it is virtual, it opens space for experimentation, discovery and reflection on good practices without risking patient safety. ${ }^{11}$ As part of the discussions about the National Patient Safety Policy, virtual simulation for health courses represents a strategy that aims to prepare students in a safe environment before dealing with the real patient in the fields of practice, enhancing their relevance in education. ${ }^{15}$

It should be noted that, in addition to the development of educational technologies, there is fundamental importance in the method that guides it and in the validation for its use. Better results will be obtained from the creation of educational technologies with scientific quality, whose learning objectives are supported by pedagogical approaches that are appropriate and validated with experts, and considering the preferences of use and needs of the target public.

It is necessary to understand educational technology not as an end in itself, nor as a substitution of the professor, but as a tool that supports practice and facilitates the student's learning processes, being able to incorporate nonconventional character through entertainment and fun. ${ }^{8}$

Another interesting reflection on the application of games in education is about the pleasant experiences that can trigger positive emotions during the study process, maximizing cognitive processes and learning, according to neuroscience studies. ${ }^{16}$ Thus, it is reiterated the importance of innovation in teaching in the face of the advances of technology, the learning needs and context of the SUS (Brazilian Unified Health System), the way the university students of this generation study and the alignment with the critical-reflexive training of nursing. ${ }^{2,8}$

\section{METHOD}

This is a methodological research involving the development and validation of the serious game e-Baby: skin integrity.
For the development of the serious game, some references of the area were combined, namely: Bernardo (1996) regarding the development of software with multimedia for the health area; Preece, Rogers and Sharp (2007), contributing to the construction of user-centered interactive design; and Marfisi-Schottman, George and Tarpin-Bernard (2010), with specifics for creating serious games. The development stages are represented by Figure 1 and described in detail below. ${ }^{17-19}$

Figure 1. Stages of methodological research to develop serious game e-Baby: skin integrity. Source: The authors.

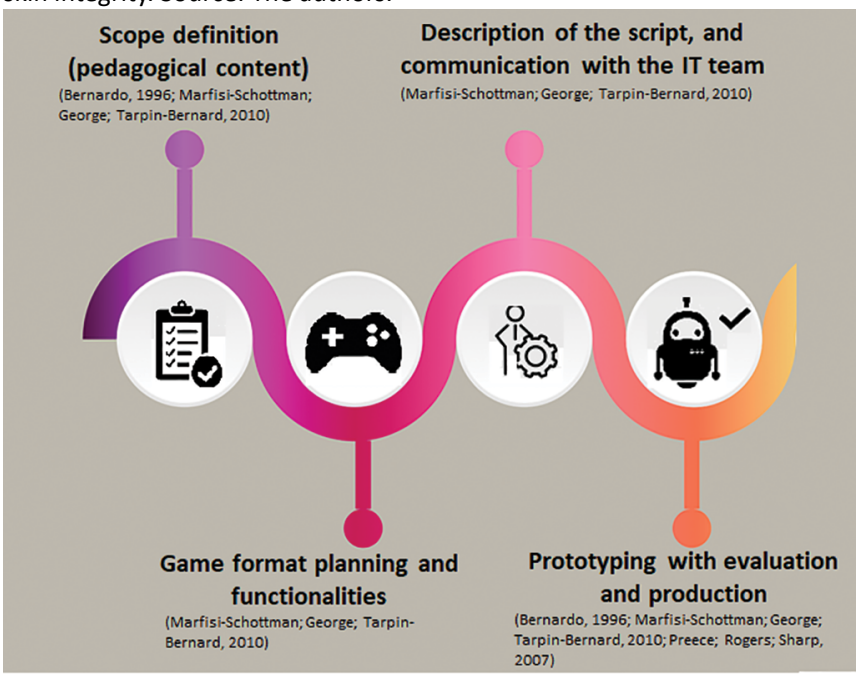

The validation was carried out with four experts: three nurses from neonatal units with graduate studies related to neonatology, two of them having experience in the development of digital technologies; and an expert with a baccalaureate diploma in computer sciences, and a master's degree in software engineering and digital educational games, one of the authors of the tools applied in this research.

The Heuristic Evaluation for Digital Educational Games (HEDEG) was used, translated, adapted and validated for its use in Brazil. The validation was conducted on May $2016 .{ }^{20}$ It should be noted that the number of experts involved in this process was determined according to the recommendation of the Nielsen benchmark that indicates between 3 and 5 experts to evaluate digital technologies. ${ }^{21}$

The tool consists of 36 items distributed in five heuristics: interface (10 items), educational elements (6 items), content (6 items), playability ( 9 items) and multimedia ( 5 items) 20 , and is summarized in Figure 2.

The experts classified the serious game according to the items of the tool, and evaluated them as shown in Chart 1, according to Nielsen: ${ }^{21}$

The criterion of validation adopted for the serious game was to obtain at least $75 \%$ of absence of errors or errors classified until type 2 for each item, and the minimum approval of $75 \%$ of 
Figure 2. Heuristics and its requirements, according to the Heuristic Evaluation for Digital Educational Games (HEDEG). Source: Adapted from Valle, Vilela, Parreira Junior, Inocencio. ${ }^{20}$

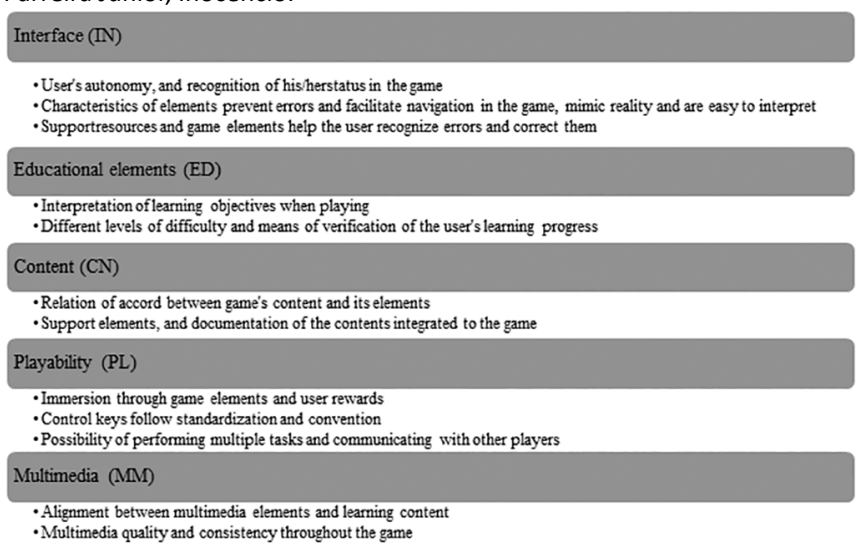

Chart 1. Heuristic usability evaluation, adapted from Nielsen (1994)

\begin{tabular}{|ll|}
\hline Concept & Description \\
\hline 0 & $\begin{array}{l}\text { Problem encountered does not necessarily } \\
\text { affect the use }\end{array}$ \\
\hline 2 & $\begin{array}{l}\text { Aesthetic problem that does not necessarily } \\
\text { require correction }\end{array}$ \\
3 & Low priority problem \\
4 & High priority problem \\
\hline
\end{tabular}

Source: Adapted from Nielsen. ${ }^{21}$

the items of each group to consider the corresponding heuristic validated, following the definition of cut of punctuation adopted in another study of technology validation. ${ }^{23}$

The data analysis used the descriptive statistics with frequencies to verify compliance with the validation criteria, mentioned above.

The research was conducted in accordance with Resolution 466 of 2012 and had approval of the Research Ethics Committee, identified by the process 638.277 and used the Informed Consent Term at the time of data collection with the experts.

\section{RESULTS}

The serious game e-Baby: skin integrity was developed with virtual simulation, which can be called using 3D technology, audio and written text, increasing the inclusion for access and its use. The development process presented below contemplated the steps provided and described in the Method section, based on:

\section{Scope definition (pedagogical content)}

The game content was defined from a dual approach: conversation rounds with nurses working in a neonatal unit, and an integrative review of the literature on clinical evaluation and skin care of the premature infant. ${ }^{24}$ For the meeting, which was the first moment, researchers carefully listened to the nurses experiences about premature infant's skin care, focusing on daily difficulties and frequent questions of students or professionals about the unit's routine. There was discussion on the theme regarding clinical conditions related to the premature infant's skin, and nursing practices.

The integrative literature review allowed us to gather and synthesize important data in the premature infant's skin care overview, bringing together important material for evidencebased clinical practice that has been incorporated into the serious game. ${ }^{24}$

The scope of the serious game was then defined into: clinical evaluation and care for diaper dermatitis, candidiasis infection, application of antiseptics before venipuncture, hygiene and adhesive handling, puncture and positioning of the temperature sensor.

\section{Definition of the game format and functionality}

The game presents the clinical case of a premature infant throughout a virtual nurse who narrates the anamnesis' relevant data and history of the clinical evaluation. Next, the challenge of clinically evaluating the premature infant and promoting nursing care according to the presented problems appears on the screen. You can see and hear the story again and again, pausing if necessary.

During the clinical evaluation and definition of nursing care, the user selects the tools that he/she deems pertinent, using the drag-and-drop technique, and others are available in the lower bar of the screen. If the chosen tool is not correct, trying to place it in the empty space on the top bar automatically returns to the available toolbar and, in some cases, generates informative feedback explaining why the tool is not suitable for the situation, justifying it based on the data obtained in the literature. If the user correctly selects the tools, the game proceeds with an animation simulating the action in a virtual setting, and then there is a question on the screen that requires clinical decision of the user.

Figure 3 below illustrates the tools available on two screens of the serious game: benzene, essential fatty acids, antifungal medication in ointment (ketoconazole), hydrocolloid, hygiene products such as water, soap and cotton, adhesives such as plaster and microporous tape, and tools indicating inspection (eye) and action through the use of hands.

There is a left sidebar on the screen that represents the points obtained in the game. At each hit, there is a visual and auditory feedback of positive feedback (hit symbol and child laugh sound) and at each error, there is a negative feedback (error symbol and baby crying sound) shows up. Thus, nursing students can measure their performance and try to improve on the next move if they wish. 
Figure 3. Screens of the serious game e-Baby: skin integrity demonstrating the available and selected toolbars, and the drag-and-drop process. Source: Authors' file (http://gruposdepesquisa.eerp.usp.br/gpecca/ebaby3/).

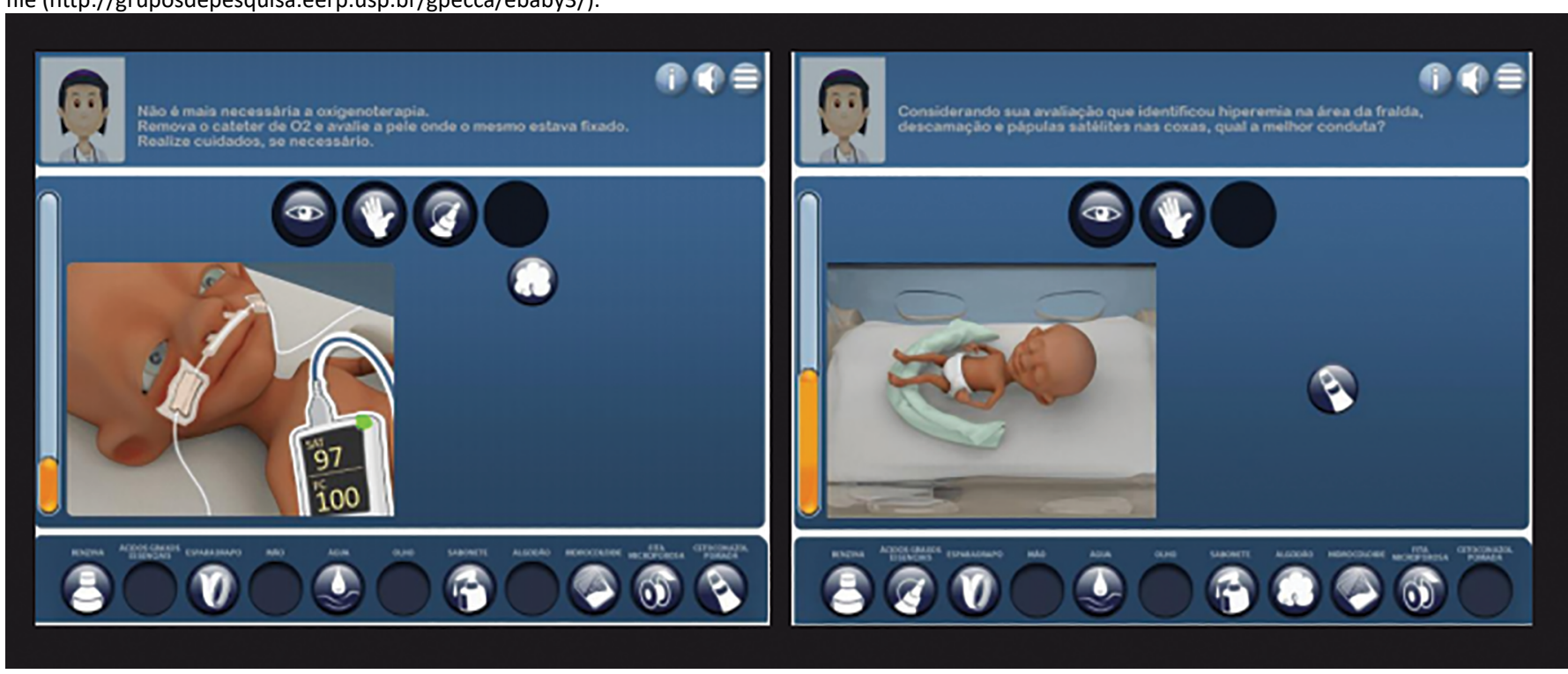

\section{Description of the script, and communication with the development team}

The most common situations that could raise questions among students during theoretical-practical activities in neonatal units were incorporated into the script, based on the experience of the researchers and nurses who participated in the stage of scope's definition, added to the scientific literature researched.

The script design followed the logic of the storyboard and described from the beginning the functionality, the text and the expected action. To facilitate communication with the software development team, it is recommended to present a wellstructured, sequential script explaining each desired action and presenting sample images that faithfully represent objects, parts of the human body, and clinical manifestations desired mimic, briefly reporting the intended learning objectives.

\section{Prototyping, evaluation and production}

This stage is fundamental to the process of developing educational technologies and consists of analyzing the prototype in detail, comparing it with the script, and identifying errors, communicating to the technology team, waiting for correction and re-evaluation.

It is an important moment that requires clear and systematic communication, and suggestions by the software development team can arise when recognizing opportunities for improvement in the playability experience, ensuring the achievement of the objectives with the technology.

In order to avoid costs with corrections in the final product of the serious game, it is recommended prototyping in a simple drawing sketch, which in this study was developed in Photoshop ${ }^{\circledR}$, on the tablet computer for Cintiq model drawing for PC, animated summary simulation and sequence analysis and playability effects through detailed description. A fundamental and recommended process for future studies as part of the method, since changes occurred in the prototype validation process. Figure 4 below shows examples of e-Baby prototype screens compared to the final product and designs of the animations that simulated the care.

After final approval, the production was the responsibility of the software development team, using the necessary adjustments and approval of the prototype. Immediately after delivery, the serious game was tested by the researchers confirming the suitability of the final product, proceeding with the validation.

The validity of the serious game was achieved in all items of all heuristics (interface, educational elements, playability, content and multimedia), and of the 36 items contained in the tool, 18 $(50 \%)$ were unanimously approved by the experts, without an errors' survey of any kind. Of the others that presented some problem, only seven were raised by more than one evaluator and none of the items presented more than $25 \%$ of problems classified as 3 or 4, confirming validation according to adopted criteria.

Graph 1 below represents the overview of absence or existence of problems, with classification of the same when identified by the experts, considering the 36 items of the tool among the five heuristics.

The errors classified in levels 3 or 4 represented in the proportion, among the total, $21 \%$ (7 errors) and 3\% (1 error), respectively, being expressive the absence of errors or low level of relevance or complexity errors. 
Figure 4. Images of the prototyping process and comparison with final product. Source: Authors' file (http://gruposdepesquisa.eerp.usp.br/gpecca/ebaby3/).
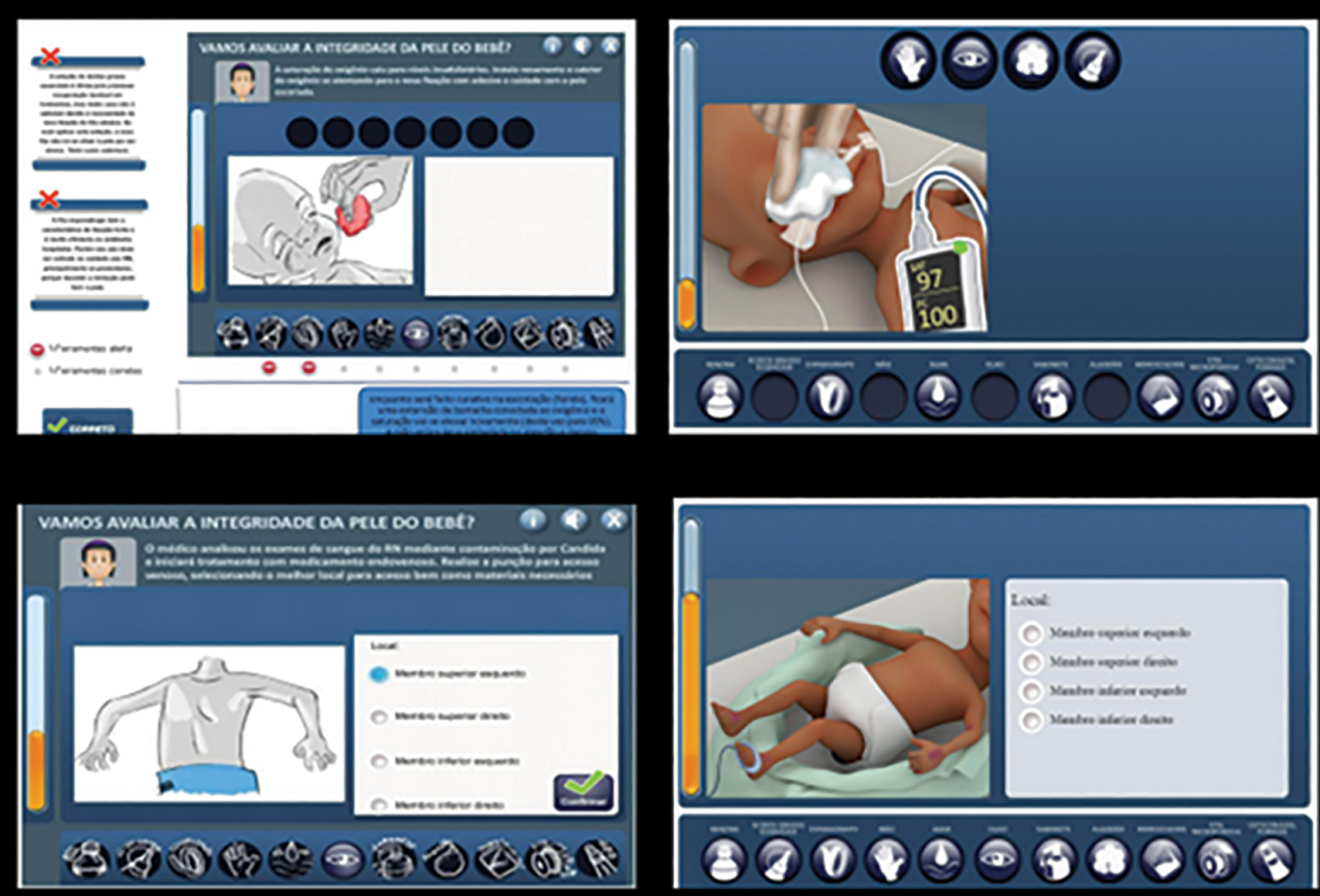

Prototype

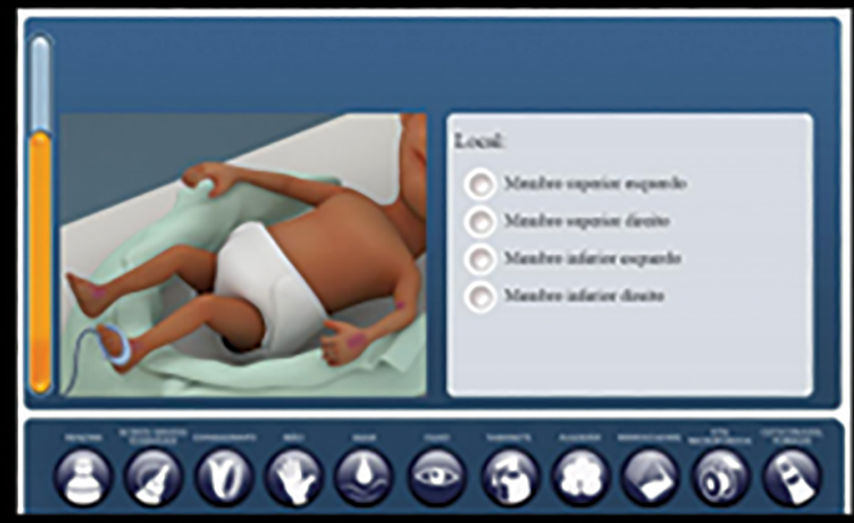

\section{Final product}

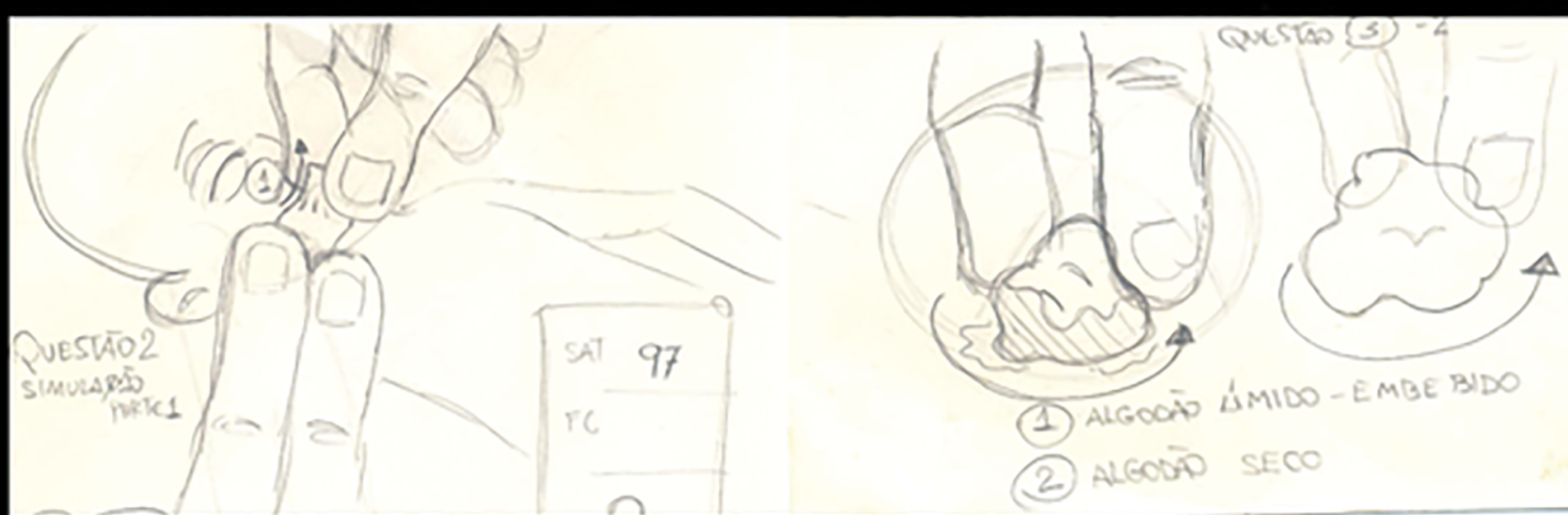


Graphic 1. Identification and classification of problems in HEDEG items by evaluated heuristics. Ribeirao Preto city, 2016. Source: The authors.

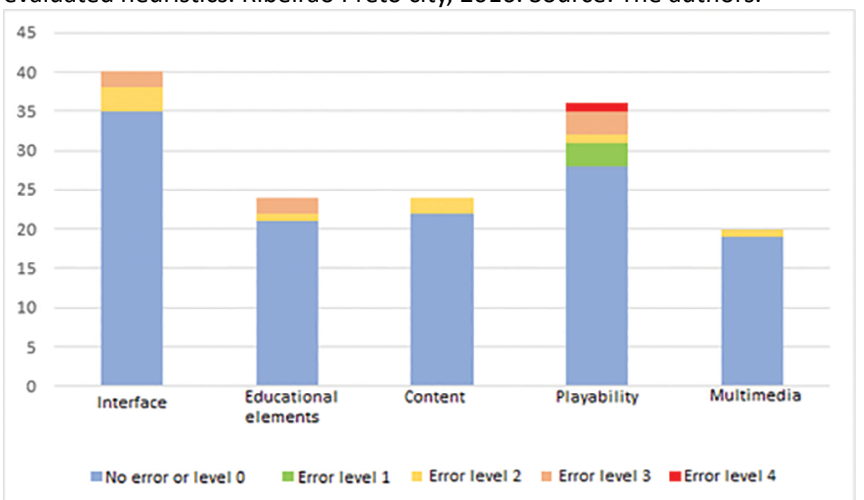

\section{DISCUSSION}

The development of the serious game followed the consolidated framework in the literature and, during the stages that preceded its production; the importance of qualified research on the subject was emphasized, contributing to the practice based on evidence. Thus, the technology presented in this study makes it possible for the student to contact national and international scientific recommendations to guide the care of the premature infant's skin. ${ }^{24}$

The access to innovative teaching technologies and strategies that contemplate health content should be based on the best scientific evidence, being this fundamental component to reach its educational purpose, and to collaborate with the quality of clinical training and practice. Thus, it is expected that students, when participating in these experiences in the teaching-learning process, study in the context of scientific literature and start practicing on the same basis. ${ }^{25}$

It is worth discussing that health behaviors are dynamic and change with the advances of research, and it is the task of those responsible for the development of educational technologies to keep up to date and modify the variables of the game whenever necessary. If this effort does not occur, the game will become obsolete and will not contribute to education properly, causing its forgetfulness or inappropriate use.

As for the achievement of the development stages, it was highlighted the articulation between a team of researchers and developers, which demands intense communication and requires well-established work processes and timetable, especially in the production and analysis of script and prototype. A recently published study reinforces the importance of this communication, considering the approximation between the teams that determine the success of the tool developed for use and application in teaching. ${ }^{22}$

The validation process is primordial to ensure the quality of the developed product, especially with a special look at the pedagogical and usability aspects considering its nature of educational technology. ${ }^{23}$
It is not possible to decouple the creation of this type of technology from the learning frameworks and objectives, since these are the basis and the motivation for the development of the teaching tools, assuming the technology role of transmitter and not main focus of the creation.

Many studies and initiatives have taken place in the field of the development of digital technologies, motivated by the analysis of effort and investment versus benefits, so that the creation and evaluation processes improve, achieving better results in the final products and their application in teaching. As examples, there is usability analysis and user-centered design, the emotional design that analyzes human computer linkage through the positive or negative emotions generated in interaction, participatory design and playability, in the context of computational-based educational

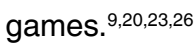

During validation, the problems encountered focused mainly on levels that do not require corrections, reinforcing that the serious game was designed in line with the interests of serving the end user in a useful, enjoyable and educational way. In this way, we discuss in this section the items of heuristics in which problems of level 3 and 4 were identified.

The only item evaluated with level 4 problem corresponds to the playability heuristic and was pointed out by only one evaluator, referring to item 4 of the JG heuristic (JG4): "Users who have successfully completed a stage of the game are rewarded". 20:252 This fact is justified because, for this evaluator, the sidebar of punctuation that fills each hit and the sound of the baby referring to happiness or laughter (different from the sound of crying when there is user error) were not considered rewards, as was the congratulatory message from the nurse at the end of the game.

Since rewards are a key attribute in digital games, the serious game is in star-gain inclusion analysis, for example, or bonuses for extra activities.

The other errors discussed were classified as level 3 , starting with item IN5 (The elements of the game are able to avoid the user error). ${ }^{20: 251}$ It is possible to argue that, in the case of a game that simulates a real situation, it is expected that it is possible for the user to commit errors, maintaining realism. Specifically in the case of e-Baby, the student has the opportunity to learn from his/her error, analyzing the arguments based on scientific literature that is provided in the explanatory feedback, being able to play again immediately after the error with a new chance to hit. However, the system partially avoids errors, so when choosing the tools that are not suitable for the clinical situation presented, the game returns them to the lower bar, indicating that it is necessary to choose another one to proceed with the animation.

In the aspects of the educational elements, items ED3 ("The elements of the game are created in order to contemplate different levels of learning, for example, beginner, intermediate and advanced") and ED5 ("The game offers the user the possibility of choosing its difficulty level"). ${ }^{20: 251}$ In fact, the serious game does not allow selection of difficulty level, since it was developed for 
undergraduate students before their first contact with the real baby in the practice fields, therefore, beginners. In spite of this, it incorporates an increase of complexity in the resolution of the clinical case, using the temporary change indication feature, that is, if in the clinical evaluation there were no atypical skin characteristics, a few days are spent in the virtual simulator and the presence of papules and hyperemia.

As for the playability, one of the errors is being analyzed by the team of developers for correction: item JG3 ("Users are able to save games in different states throughout the game"). ${ }^{20: 252}$ In agreement with the experts and with HEDEG, this is an important feature because it prevents that whenever the user closes the web page, it can resume the progress made so far.

In contrast, considering the scope of the game, its dynamics and learning objectives, it is not intended to be modified within the scope of item JG8 ("There are elements in the game that allow the user to communicate with other users as well as objects of the NPC type Non-player Character, in order to achieve their goals"). ${ }^{20: 252}$ There is an NPC-type object in the game, characterized by the nurse who passes the call on with information necessary to perform the clinical case, but does not intend to incorporate it as a consistent element to assist the student in the decisions during the game, maintaining the level of difficulty as planned.

Finally, item JG9 ("The game is able to offer the user the ability to perform more than one task at a time") 20:252 was identified with an error level 3 by an expert, and the justification for not modifying this one aspect of the educational technology was that it is not intended to offer the user the possibility of multiple tasks at the same time, but rather to use concentration to achieve each one of them, progressing in learning without distractions.

Analyzing the validation process, it is worth discussing that there are different digital games and that the usability and playability heuristics may vary depending on the objectives they carry, requiring further studies in the area to assign weights to the evaluated items depending on the nature of the game technology.

\section{CONCLUSIONS AND IMPLICATIONS FOR PRACTICE}

The serious game e-Baby: Skin Integrity is a virtual simulation educational technology validated by experts to be used with nursing students. The game offers educational experience that virtually simulates the real challenges of clinical practice with the premature infant, aiming at better preparation of students in a safe environment and study opportunity that precedes the actions in the neonatal unit.

It is valid as to its interface, if it is pleasant and easy to understand for the user; in relation to the educational elements, being compatible with the learning objectives that it proposes; in terms of content, considering scientific bases that guide the practice learned in the game; in front of the playability heuristic, contemplating aspects of entertainment and, finally, of multimedia, considering the suitability of the graphical features that it presents in 3D technology and simultaneous use of sound and text.

As the study limitation, we present the non-inclusion of nursing students, the final public, in the process of developing the serious game, corresponding to the so-called participatory design. Thus, it is suggested that future studies whose objective is the creation of digital educational technologies, incorporate such practice from the conception of the prototype.

We believe that the serious game e-Baby: skin integrity can contribute as a resource to support teaching practice and the teaching-learning process also from the perspective of the student, offering a differentiated tool to study and simulate real situations. It is an educational technology that can be repeated and used in any device with internet access, allows errors and enables further attempts with immediate and informative feedback support, and includes evidence from the health area for epidemiologically relevant problems, maximizing its use in training for the SUS.

\section{REFERENCES}

1. Pelizzari A, Kriegl ML, Baron MP, Finck NTL, Dorocinski SI. Teoria da Aprendizagem Significativa Segundo Ausubel. Rev PEC (Curitiba) [Internet]. 2002 Jul;2(1):37-42. Available from: http://portaldoprofessor mec.gov.br/storage/materiais/0000012381.pdf

2. Ministério da Educação (BR). CNE/CSE. Resolução № 3 de 7 de novembro de 2001. Institui Diretrizes Curriculares Nacionais do Curso de Graduação em Enfermagem. Brasília (DF): Ministério da Educação; 2001.

3. Liu L, Oza S, Hogan D, Perin J, Rudan I, Lawn JE, et al. Global, regional, and national causes of child mortality in 2000-13, with projections to inform post-2015 priorities: an updated systematic analysis. Lancet [Internet]. 2015 Jan;384:430-40. Available from: https://www.ncbi.nlm. nih.gov/pubmed/?term=3.\%09Liu+L\%2C+Oza+S\%2C+Hogan+D\%2 $\mathrm{C}+$ Perin+J\%2C+Rudan+1\%2C+Lawn+JE\%2C+Cousens+S\%2C+Ma thers+C\%2C+Black+RE.+Lancet. +2015

4. World Health Organization (WHO). Born too soon: the global action report on preterm birth. Geneva: World Health Organization; 2012.

5. Freire P. Pedagogia do oprimido. $62^{\mathrm{a}}$ ed. Rio de Janeiro: Paz e Terra; 2016.

6. Reinaldo F, Magalhães DR, Reis LP, Gaffuri S, Freddo A, Hallal R. Impasse aos Desafios do uso de Smartphones em Sala de Aula Investigação por Grupos Focais. RISTI Rev Iber Sist Tecnol Inf [Internet] 2016;19(9):77-92. Available from: http://www.scielo.mec.pt/pdf/rist/n19/ $\mathrm{n} 19 \mathrm{a} 07$

7. Watts L. Synchronous and Asynchronous Communication in Distance Learning: A Review of the Literature. Quart Rev Dist Educ [Internet] 2016;17(1):23-32. Available from: https://eric.ed.gov/?id=EJ1142962

8. Aredes NDA, Góes FSN, Silva MAI, Gonçalves MFC, Fonseca LMM. Digital object in neonatal nursing: impact on student's learning. Rev Eletr Enferm [Internet].2015 Oct/Dec;17(4):1-10. Available from: https:// www.fen.ufg.br/revista/v17/n4/pdf/v17n4a10-en.pdf

9. Fonseca LM, Dias DM, Góes Fdos S, Seixas CA, Scochi CG, Martins $\mathrm{JC}$, et al. Development of the e-Baby serious game with regard to the evaluation of oxygenation in preterm babies: contributions of the emotional design. Comput Inform Nurs [Internet]. 2014 Sep;32(9):42836. Available from: https://www.ncbi.nlm.nih.gov/pubmed/?term=Deve lopment+of+the+e-Baby+serious+game+with+regard+to+the+evalua tion+of+oxygenation+in+preterm+babies 
10. Carlidge P. The epidermal barrier. Semin Neonatol [Internet]. 2000 Nov;5(4):273-80. Available from: https://www.ncbi.nlm.nih.gov/pubm ed/?term $=10 . \% 09$ Carlidge+P.+The+epidermal+barrier.+Semin+Neon atol $+2000 \% 3 \mathrm{~B}+5(4) \% 3 \mathrm{~A} 273 \% \mathrm{E} 2 \% 80 \% 9380$

11. Fonseca LMM, Aredes NDA, Scochi CGS. Simulação em ambiente virtual de aprendizagem: inovação na área de enfermagem neonatal. In: Mendes IA, Mazzo A, Martins JCA, orgs. Simulação no ensino de enfermagem: bases teóricas. Ribeirão Preto: Sociedade Brasileira de Comunicação em Enfermagem (SOBRACEn); 2014. p. 241-57.

12. Boyle EA, Hainey T, Conolly TM, Gray G, Earp J, Ott M, et al. An update to the systematic literature review of empirical evidence of the impacts and outcomes of computer games and serious games. Comput Educ [Internet]. 2016 Mar;94:178-92. Available from: https:// www.sciencedirect.com/science/article/pii/S0360131515300750

13. Instituto Brasileiro de Geografia e Estatística (IBGE) (BR). Pesquisa Nacional por Amostra de Domicílios. Síntese de Indicadores. Informação e Documentação. Rio de Janeiro: Instituto Brasileiro de Geografia e Estatística; 2016

14. Ferguson C, Davidson PM, Scott PJ, Jackson D, Hickman LD. Augmented reality, virtual reality and gaming: an integral part of nursing. Contemp Nurse [Internet]. 2015;51(1):1-4. Available from: https://www. ncbi.nlm.nih.gov/pubmed/?term=Augmented+reality\%2C+virtual+real ty+and+gaming $\% 3 \mathrm{~A}+$ an+integral+part+of+nursing.+Contemporary+N urse.+2015\%3B51(1)\%3A1\%E2\%80\%934

15. Ministério da Saúde (BR). Portaria № 529, de 1 de abril de 2013. Institui o Programa Nacional de Segurança do Paciente (PNSP). Brasília (DF): Ministério da Saúde; 2013

16. Vogel S, Schwabe L. Learning and memory under stress: implications for the classroom. Sci Learn [Internet].2016;1(16011):1-10. Available from: https://www.nature.com/articles/npjscilearn201611.pdf. DOI: 10.1038/ npjscilearn.2016.11

17. Bernardo V. Metodologia para desenvolvimento de projeto multimídia aplicado ao ensino da medicina [dissertação]. São Paulo: Universidade Federal de São Paulo; 1996.

18. Preece J, Rogers $Y$, Sharp H. Interaction Design: Beyond Human Computer Interaction. New York: John Wiley \& Sons; 2007.
19. Marfisi-Schottman I, George S, Tarpin-Bernard F. Tools and Methods for Efficiently Designing Serious Games. In: Proceedings of the 4th European Conference on Games Based Learning ECGBL; 2010 Oct 21-22; Copenhagen, Denmark.

20. Valle PH, Vilela RF, Parreira Junior PA, Inocencio CG. HEDEG Heurísticas para Avaliação de Jogos Educacionais Digitais. In: Nuevas Ideias en Informática Educativa TISE. Anais da XVIII Conferência Internacional sobre Informática na Educação. 2013 Dec 9-11; Porto Alegre, RS, Brasil. p. 247-56.

21. Nielsen J. Usability Inspection Methods Conference companion on Human factors in computing systems. In: Proceedings of $\mathrm{CHI}$ '94 Conference Companion on Human Factors in Computing Systems 1994 Apr 24-28; Boston, MA, USA.

22. Diehl LA, de Souza RM, Gordan PA, Esteves RZ, Coelho IC. Gaming Habits and Opinions of Brazilian Medical School Faculty and Students: What's Next? Games Health J [Internet]. 2014 Apr;3(2):79-85. Available from: https://www.ncbi.nlm.nih.gov/pubmed/?term=Gaming+Habits+an $\mathrm{d}+$ Opinions+of+Brazilian+Medical+School+Faculty+and+Students $\% 3$ A+What $\%$ E2\%80\%99s+Next\%3F

23. Góes FSN, Fonseca LMM, Furtado MCC, Leite AM, Scochi CGS. Avaliação do objeto virtual de aprendizagem "Raciocínio diagnóstico em enfermagem aplicado ao prematuro". Rev Latino Am Enferm [Internet]. 2011;19(4):8 telas. Available from: http://www.scielo.br/pdf/rlae/v19n4/pt_07.pdf

24. Aredes NDA, Santos RCA, Fonseca LMM. Skin care of premature newborns: integrative review. Rev Eletr Enferm [Internet]. 2017;19:1-25. Available from: $\mathrm{https}$ ://www.revistas.ufg.br/fen/article/view/43331/25159

25. Ryan M, Holland M. Preparing Prelicensure Nursing Students for Clinical Practice in Pediatric Acute Care Settings and Interprofessional in Situ Simulation. In: Campbell SH, Daley KM. Simulation Scenarios for Nursing Educators: Making it Real. 3rd ed. New York: Springer; 2017.

26. DeSmet A, Thompson D, Baranowski T, Palmeira A, Verlogine M De Bourdeaudhuij I. Is Participatory Design Associated with the Effectiveness of Serious Digital Games for Healthy Lifestyle Promotion? A Meta-Analysis. J Med Internet Res [Internet]. 2016 Apr;18(4):e94 Available from: https://www.ncbi.nlm.nih.gov/pubmed/?term=ls+part cipatory+design+associated+with+the+effectiveness+of+serious+dig ital+games+for+healthy+lifestyle+promotion\%3F+A+meta-analysis 